\title{
Et brev fra Rønnebæksholm af 22. november 1847
}

\author{
Af Kim Arne Pedersen
}

Det fortælles blandt ældre Grundtvig-forskere, at Grundtvigs og Marie Tofts sønnedatter, Marie Grundtvig Lorange (1883-1965), gift og bosat i Norge, lod bedsteforældrenes korrespondance blive kaminens bytte. ${ }^{1}$ Beslutninger af den art bør man som forsker respektere. Ikke alt kan uden videre siges at være offentlig ejendom, heller ikke, når der er tale om skriftligt materiale, der hidrører fra en af danmarkshistoriens store skikkelser. Marie Grundtvig Loranges beslutning gør det imidlertid vanskeligt at skrive detaljeret om forholdet mellem Grundtvig og Marie Toft (1813-54) i tiden fra de mødtes i efteråret 1845 og i årene op til ægteskabet den 24. oktober $1851 .^{2}$ Et enkelt brev fra 1847 har imidlertid overlevet flammerne. Brevet er i 1990'erne kommet til Danmark via Marie Grundtvig Loranges søn, Fredrik Grundtvig Lorange, og befinder sig nu på Rigsarkivet. ${ }^{3}$ Man kan kun gisne om, hvorfor Marie Lorange ikke brændte dette brev, men muligvis skyldes det, at der er tale om et brev, der angår en konkret sag og kun i slutningen lader Marie Tofts følelser komme til udtryk.

Brevet handler i hovedsagen om udsendelsen af andet oplag af Kirke-Psalmer udgivne til Prøve af Kjøbenhavns geistlige Convents Psalme-Comitee, udkommet på C. A. Reitzels Forlag i 1845, almindeligvis som i brevet her kaldet "Prøvehæftet". Prøveheftets forord var undertegnet af J. H. Paulli, N. F. S. Grundtvig, H. Martensen og P. J. Spang, det vil sige medlemmerne af det udvalg i Københavns Præstekonvent, der stod bag udarbejdelsen med Grundtvig som en afgørende, men langtfra enerådende kraft. Prøveheftet fik ikke konventet med sig, hvad der harmede Grundtvig (Brun 1882, I, 262). I artiklen "Psalmebogs-Sagen i Danmark" fra Dansk Kirketidende nr. 3, 19. oktober 1845 har han givet sin fremstilling af sagen og et forsvar for Prøveheftet. Den 14. januar 1846 blev der afholdt afstemning i konventet, og prøveheftet forkastedes da endeligt (SJ II, 269). Bestræbelser på at få

Henning Høirup udarbejdede i sin tid sin bog om Grundtvigs og Marie Tofts søn Frederik Lange Grundtvig på baggrund af materiale fra Marie Grundtvig Lorange (Høirup 1955, 35 og 85).

2 Til Marie Toft og hendes første møde med Grundtvig, se Jutta BojsenMøllers skildring (Bojsen-Møller 2007, 5 ff.). En fornem redegørelse for betydningen af mødet med Marie Toft i Grundtvigs salmedigning finder man hos Peter Balslev-Clausen (Balslev-Clausen 1991, 134 ff. og 203 ff.).

3 Brevet indgår i en større samling materiale af personalhistorisk relevante dokumenter fra den grundtvigske slægt, af Henning Høirup tilføjet en registrant med redegørelse for hver enkelt tekst. 
prøveheftet anerkendt fortsatte ind i 1847. J. P. Mynster fortæller ifølge Johansen således, at Grundtvig arbejdede på at få en "Petition" (SJ IV, 113 f.) i stand blandt sine tilhørere om, at det måtte bruges i Vartov kirke. I en resolution af 12. maj 1847 udtalte kongen, at han ikke fandt sig foranlediget til at "tillade Brugen af bemeldte Prøvehefte ved den offentlige Gudstjeneste, i det mindste ikke, før Andragende derom indkommer fra flere Menigheder" (SJ II, 270). Steen Johansen formoder, at denne udtalelse har foranlediget Grundtvig til at udsende det nye oplag, der udkom 15. december 1847 (SJ IV, 114), men med årstallet 1848 på titelbladet (SJ II, 269). Brevet fra Marie Toft bekræfter Steen Johansens formodning om, at Grundtvig "har regnet med hurtigt at kunne fremskaffe flere" (SJ II, 270) andragender om tilladelse til brug ved gudstjenesten. Personer i det grundtvigske netværk er blevet sat i arbejde, og Marie Tofts besøg i Næstved er et vidnesbyrd om, blandt hvem og på hvilken måde der virkedes for sagen. Den omtalte Barfod er således pastor Peter Marius Barfod (1813-89), på det tidspunkt overlærer ved borgerskolen og ordineret kateket i Næstved. Han var broder til historikeren og politikeren Frederik Barfod (1811-96), og dermed går der tråde fra det grundtvigske miljø i Næstved til den kreds af sammenbragte børn, der ved giftermålet mellem enken Kristine Charlotte La Cour (1777-1826) og enkemanden Hans Peter Barfod (1770-1841) knyttedes til hinanden, og som gennem ikke mindst Frederik Barfod påvirkedes i grundtvigsk retning (Lillelund 1924, 1 ff). Peter Marius Barfod stiftede sammen med Frederik Engelhardt Boisen (1808-82), dengang præst i Skørping, en aflægger af Grundtvigs Danske Samfund i Næstved. ${ }^{4}$ Da Grundtvig i 1846 talte i Næstveds Danske Samfund, var Marie Toft ifølge Frederik Engelhardt Boisens hustru Eline Boisens erindringer "for stor Pietist" (Bojsen-Møller 2007, 36) til at deltage i mødet, skønt Grundtvig boede på Rønnebæksholm. Grundtvig deltog imidlertid i 1848 for anden gang i Danske Samfunds møde i Næstved, og da var hun med (Bojsen-Møller 2007, 38). Marie Tofts brev er sammen med Peter Marius Barfods folkeligt-nationale engagement et eksempel på, at den grundtvigske bevægelse i 1840'erne for alvor er ved at træde i karakter. Barfods indsats i forening såvel som salmesag er karakteristisk for bevægelsens dobbeltsporede, dvs. såvel folkelige som kirkelige, virke. Hen ad vejen har også Marie Toft accepteret Grundtvigs folkelige tanker og udvidet sin medvirken til omfatte dem. Det ses af brevet, at Grundtvig ikke blot var en samlende skikkelse, men også handlede aktivt inden for netværket og af grundtvigianerne accepteredes som den, hvis beslutninger var afgørende.

$4 \quad \mathrm{http}: / / \mathrm{www} . b a r f o d-b a r f o e d . d k /$ stamtavle/ 
Kjære Hr Pastor Grundtvig!

Her paa Egnen haaber jeg nok det vil gaae ganske godt med den omtalte Bøn til Kongen om Prøvehæftet. - Jeg tog Dagen efter at jeg var kommen hjem fra Kbh: ind til Barfod i Nestved, for at faae ham til at tage sig af Sagen, og jeg troer ogsaa nok han har været ret flink. Iaften var jeg inde hos ham igjen, og saa bad han mig skrive til Dem, for at høre Deres Mening, om det var nødvendigt, at hvad der i denne Anledning blev indsendt, skulde stiles som en Ansøgning til Kongen, eller om vi kunde stile det til Dem, som Vidnesbyrd om Stemningen for Sagen. - Vil De svare mig snarest muligt herpaa, da vi have aftalt i næste Uge at samle alle dem som maatte interessere sig for Sagen. -

Tak for sidst, Gud skee Lov at jeg kom ind til Dem. - Naar jeg vil unde mig selv en rigtig stor Glæde, saa læser jeg Deres sidste to Breve. - Levvel, levvel: Vor Herre velsigne Dem. -

Deres hjertelig hengivne Marie Toft.

\section{Forkortelser}

SJ I-IV: Steen Johansen (1948-54), Bibliografi over N. F. S. Grundtvigs Skrifter, bind 1-4, København.

\section{Litteraturliste}

Balslev-Clausen, Peter (1991), Det vingede ord: Om N. F. S. Grundtvigs salmedigtning, Frederiksberg.

Bojsen-Møller, Jutta (2007), Grundtvig og Marie: En fortcelling fra Rønnebceksholm, Næstved.

Brun, H. (1882), Biskop N. F. S. Grundtvigs Levnetsløb, udførligst fortalt fra 1839. Et Bidrag, bind 1-2, Kristiania.

Høirup, Henning (1955), Frederik Lange Grundtvig, København.

Johansen, Steen (1948-54), Bibliografi over N. F. S. Grundtvigs Skrifter, bind 1-4, København.

Lillelund, Charlotte (1924), "Minder om Præsten Christian La Cour og Jacobine La Cour, f. Bregendahl, og om deres Hjem", bind 4 i Minder fra gamle grundtvigske Hjem, bind 1-6, samlede og udgivne af Dr. H. P. B. Barfod, København. 